\title{
Om kildekritikk og liknende emner
}

Jørgen Sandemose 
Høyskolen i Oslo og Akershus har i sitt tidsskrift («Fleks» Vol. 2, No. 2 - Festskrift til Tore Linné Eriksen - 2015, red anm) nylig trykket en artikkel av universitetsprofessor, historiker Knut Kjeldstadli, omkring livsverket til Tore Linné Eriksen. I denne artikkel står følgende å lese:

"Tore har tatt tunge motstandere når det var fortjent. Blant dem som neppe med glede husker sammenstøtene med vår mann, ... er Jørgen Sandemose, som mente at folket i landa i Sør ikke burde gjøre opprør fordi kapitalismen og klasseutviklingen der ikke var drevet til et adekvat nivå."

Jeg har kontaktet både Eriksen og Kjeldstadli om dette. De svar jeg har fătt, indikerer sterkt at ingen av dem vil trekke tilbake påstanden om mine synspunkter, samt at de står i ledtog med hverandre når det gjelder produksjonen av den.

Også uavhengig av mangelen på terminologisk presisjon i Kjeldstadlis utlegning, kan det uten problemer slås fast at jeg aldri noensinne har stått for slike standpunkter, at jeg aldri har lagt fram synspunkter som kan misforstås i den retning det er tale om, og at jeg ved enhver aktuell anledning har hevdet stikk motsatte posisjoner. Dette har Eriksen, som formodentlig er Kjeldstadlis kilde for oppspinnet, vært klar over i lang tid. 